\title{
Choice of Antihyperglycemic Agents in Patients with Chronic Kidney Disease
}

\author{
Soe Naing ${ }^{1 *}$ and Cho Cho Khine ${ }^{1,2}$ \\ ${ }^{1}$ Department of Internal Medicine, University of California, USA \\ ${ }^{2}$ Department of Nephrology, Veterans Affairs Central California Health Care System, USA
}

*Corresponding author: Soe Naing, Associate Clinical Professor of Medicine, Director of Division of Endocrinology, Medical Director of Community Diabetes Care Center, University of California, San Francisco-Fresno Medical Education Program, Dept. of Internal Medicine, Suite A 2823 Fresno Street, Fresno, CA 93721, USA

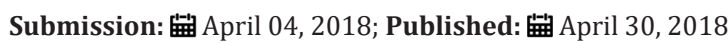

Keywords: Chronic kidney disease; Antihyperglycemic agents; Diabetes mellitus

\section{Mini Review}

Chronic kidney disease (CKD) is one of the most frequent microvascular complications of diabetes. Approximately $40 \%$ of adults with type 2 diabetes mellitus (T2DM) have CKD and about $50 \%$ of end-stage renal disease (ESRD) is caused by diabetes [1,2]. The hypoglycemia risk is increased in patients with advanced CKD (CKD stages 4 \& 5) since clearance of insulin and of some of the non-insulin antihyperglycemic agents is reduced and there is an

Table 1: Recommended dose adjustments for antihyperglycemic agents in CKD [1,7,17-19].

\begin{tabular}{|c|c|c|c|}
\hline Medications & & $\begin{array}{c}\text { Dose Adjustment Based on CKD } \\
\text { Stage }\end{array}$ & \\
\hline Class & Compounds & Predialysis CKD (CKD stage 1-4) & $\begin{array}{c}\text { Dialysis patients (ESRD/CKD } \\
\text { stage 5) }\end{array}$ \\
\hline \multirow[t]{3}{*}{ Biguanides } & Metformin & No dose adjustment if eGFR>45 & Avoid \\
\hline & & Do not initiate if eGFR $30-45$ & \\
\hline & & Discontinue if eGFR $<30$ & \\
\hline \multirow[t]{3}{*}{ Sulfonylureas (2nd generation) } & Glyburide & Avoid & Avoid \\
\hline & Glipizide & $\begin{array}{l}\text { Initiate conservatively at } 2.5 \mathrm{mg} \\
\text { daily. No dose adjustment required }\end{array}$ & $\begin{array}{l}\text { Initiate conservatively at } 2.5 \mathrm{mg} \\
\text { daily. No dose adjustment required }\end{array}$ \\
\hline & Glimepiride & $\begin{array}{l}\text { Initiate conservatively at } 1 \mathrm{mg} \text { daily. } \\
\text { Dose titration and maintenance } \\
\text { dosing should be conservative to } \\
\text { avoid hypoglycemia. }\end{array}$ & Avoid \\
\hline \multirow[t]{2}{*}{ Meglitinides (glinides) } & Repaglinide & $\begin{array}{c}\text { Initiate conservatively at } 0.5 \mathrm{mg} \\
\text { with meals if eGFR<30 }\end{array}$ & $\begin{array}{l}\text { No specific dosage adjustments } \\
\text { provided in the manufacturer's } \\
\text { labeling }\end{array}$ \\
\hline & Nateglinide & $\begin{array}{l}\text { Initiate conservatively at } 60 \mathrm{mg} \\
\text { with meals if eGFR }<30\end{array}$ & $\begin{array}{l}\text { No specific dosage adjustments } \\
\text { provided in the manufacturer's } \\
\text { labeling }\end{array}$ \\
\hline Thiazolidinediones & Pioglitazone & No dose adjustment required & No dose adjustment required \\
\hline$\alpha$-glucosidase inhibitors & Acarbose & Avoid if eGFR<30 & Avoid \\
\hline
\end{tabular}

impaired renal gluconeogenesis with reduced kidney mass $[3,4]$. used safely to manage diabetes in patients with CKD is therefore, limited and insulin dose usually requires an adjustment to avoid hypoglycemia. It is important that the choice of antihyperglycemic agents is reviewed regularly as CKD stage advances and the doses are readjusted based on CKD stage to avoid hypoglycemia (Table 1). The number of non-insulin antihyperglycemic agents that can be 


\begin{tabular}{|c|c|c|c|}
\hline & Miglitol & Avoid if eGFR $<25$ & Avoid \\
\hline \multirow[t]{9}{*}{ DPP-4 inhibitors } & Sitagliptin & $100 \mathrm{mg}$ daily if eGFR>50 & 25 mg daily \\
\hline & & $50 \mathrm{mg}$ daily if eGFR $30-50$ & \\
\hline & & 25 mg daily if eGFR $<30$ & \\
\hline & Saxagliptin & $5 \mathrm{mg}$ daily if eGFR $>50$ & $2.5 \mathrm{mg}$ daily \\
\hline & & $2.5 \mathrm{mg}$ daily if eGFR $\leq 50$ & \\
\hline & Linagliptin & No dose adjustment required & No dose adjustment required \\
\hline & Alogliptin & $25 \mathrm{mg}$ daily if eGFR $>60$ & $6.25 \mathrm{mg}$ daily \\
\hline & & $12.5 \mathrm{mg}$ daily if eGFR $30-60$ & \\
\hline & & $6.25 \mathrm{mg}$ daily if eGFR $<30$ & \\
\hline Bile acid sequestrants & Colesevelam & No dose adjustment required & No dose adjustment required \\
\hline Dopamine- 2 agonists & Bromocriptine (quick release) & $\begin{array}{l}\text { No dosage adjustments provided in } \\
\text { the manufacturer's labeling }\end{array}$ & $\begin{array}{c}\text { No specific dosage adjustments } \\
\text { provided in the manufacturer's } \\
\text { labeling }\end{array}$ \\
\hline \multirow[t]{7}{*}{ SGLT2 inhibitors } & Canagliflozin & $\begin{array}{l}\text { No dose adjustment required if } \\
\qquad \mathrm{eGFR}>60\end{array}$ & Avoid \\
\hline & & $100 \mathrm{mg}$ daily if eGFR $45-59$ & \\
\hline & & Avoid if eGFR $<45$ & \\
\hline & Dapagliflozin & Avoid if eGFR $<60$ & Avoid \\
\hline & Empagliflozin & $\begin{array}{c}\text { No dose adjustment required if } \\
\text { eGFR } \geq 45\end{array}$ & Avoid \\
\hline & & Avoid if eGFR $<45$ & \\
\hline & Ertugliflozin & Avoid if eGFR $<60$ & Avoid \\
\hline \multirow[t]{8}{*}{ GLP-1 receptor agonists } & Exenatide & Not recommended with eGFR $<30$ & Avoid \\
\hline & Exenatide (extendedrelease) & Not recommended with eGFR $<30$ & Avoid \\
\hline & Liraglutide & $\begin{array}{l}\text { No specific dose adjustment } \\
\text { recommended by the manufacturer }\end{array}$ & $\begin{array}{l}\text { Limited experience. Manufacturer } \\
\text { recommends cautious use. }\end{array}$ \\
\hline & & $\begin{array}{l}\text { No dose adjustment required if } \\
\qquad \text { GGFR }>15\end{array}$ & $\begin{array}{l}\text { No specific dosage adjustments } \\
\text { provided in the manufacturer's } \\
\text { labeling }\end{array}$ \\
\hline & Albiglutide & $\begin{array}{l}\text { No dose adjustment required if } \\
\qquad \mathrm{eGFR} \geq 30\end{array}$ & Avoid \\
\hline & Lixisenatide & $\begin{array}{l}\text { No dosage adjustments provided in } \\
\text { the manufacturer's labeling if eGFR } \\
15-29\end{array}$ & \\
\hline & Dulaglutide & $\begin{array}{l}\text { No specific dose adjustment } \\
\text { recommended by the manufacturer }\end{array}$ & $\begin{array}{l}\text { Limited experience. Manufacturer } \\
\text { recommends cautious use. }\end{array}$ \\
\hline & Semaglutide & $\begin{array}{l}\text { No dose adjustment required per } \\
\text { manufacturer }\end{array}$ & $\begin{array}{c}\text { No dose adjustment required per } \\
\text { manufacturer }\end{array}$ \\
\hline Amylin mimetics & Pramlintide & $\begin{array}{l}\text { No dose adjustment required if } \\
\qquad \mathrm{eGFR}>15\end{array}$ & $\begin{array}{c}\text { Limited experience. No specific } \\
\text { dosage adjustments provided in the } \\
\text { manufacturer's labeling }\end{array}$ \\
\hline Insulins & & $\begin{array}{l}\text { Lower insulin doses required with a } \\
\text { decrease in eGFR. }\end{array}$ & $\begin{array}{l}\text { Lower insulin doses required with a } \\
\text { decrease in eGFR. }\end{array}$ \\
\hline
\end{tabular}

Metformin is recommended as monotherapy of choice in patients with T2DM, and it is mostly eliminated unchanged in the urine. Lactic acidosis is a rare and serious side effect of metformin in CKD patients. The previous black box warningstated that metformin was contraindicated in men with a serum creatinine $>1.5 \mathrm{mg} / \mathrm{dL}$ and women $>1.4$. The United States Food and Drug Administration (FDA) revised the warnings in 2016, and the new recommendation indicates that it can be continued until eGFR is $30 \mathrm{~mL} / \mathrm{min} / 1.73 \mathrm{~m}^{2}$ and that it can be initiated if it is $>45 \mathrm{~mL} / \mathrm{min} / 1.73 \mathrm{~m}^{2}$ [5].
First-generation sulfonylureas (chlorpropamide, tolazamide, and tolbutamide) are contraindicated in CKD due to increased half-lives and the risk of hypoglycemia. Of second-generation sulfonylureas, glyburideis not recommended for use in CKD as its active metabolites are eliminated in urine. Glimepiride is primarily metabolized by the liver, but its active metabolites are excreted by kidney;it can be used with the dose reduction in CKD. Glipizide ismetabolized by the liver and mainlyeliminated in the urine as inactive metabolites. Therefore,dose adjustmentisusually not 
required and it is considered the preferred choice of sulfonylureain CKD $[6,7]$. Of glinides, repaglinideis metabolized by the liver and mainly excreted in the feces; therefore, with a lower starting dose, it can be used in advanced CKD or ESRD. However, active metabolites of nateglinideare mostly eliminated in urine, and thus it should be used with caution in advanced CKD [7,8]. The thiazolidinedione, pioglitazone, is metabolized by the liver; therefore, dosage adjustment is not necessary. Acarbose and miglitol, $\alpha$-glucosidase inhibitors, are not significantly absorbed from the gastrointestinal tract, but increased levels of the metabolites are observed in CKD. Therefore, these agents are not recommended in patients with $\mathrm{eGFR}<30 \mathrm{~mL} / \mathrm{min} / 1.73 \mathrm{~m}^{2}$ [4].

Dipeptidyl peptidase (DPP-4) inhibitors are usually effective and relatively safe in CKD and ESRD patients.Saxagliptin, alogliptinand sitagliptinrequire dose adjustmentin CKD. Dose reduction is not needed for linagliptin since renal excretion is low $[9,10]$. Of GLP-1 receptor agonists, exenatide is predominantly excreted via the kidney; therefore, it is not recommended in patients with eGFR $<30 \mathrm{~mL} / \mathrm{min} / 1.73 \mathrm{~m}^{2}$ [11]. Other GLP-1 receptor agonists do not require dosage adjustment [12]. The glycemic efficacy of sodium-glucose cotransporter 2 inhibitors depends on glucose filtration through the kidney, and therefore these are not recommended in patients with advanced CKD. Dapagliflozinshould be avoided in patients with eGFR $<60 \mathrm{~mL} / \mathrm{min} / 1.73 \mathrm{~m}^{2}$ since it is primarily excreted by the kidney. Ertugliflozin has minimal urinary excretion, but there is the increased exposure with declining renal function,and thus it is not recommended in those with eGFR $<60$ $\mathrm{mL} / \mathrm{min} / 1.73 \mathrm{~m}^{2}$ [13]. Empagliflozin and canagliflozinareexcreted in both feces and urine and are not recommended if eGFR is $<45$ [14-16].

For most hemodialysis patients or in advanced CKD, insulin is the effective and probably safer option. There is a higher risk of hypoglycemia due to reduced renal clearance, and therefore a reduction in the starting dose and gradual dose titration is recommended [17]. For hemodialysis patients and for CKD patients with eGFR $<10 \mathrm{~mL} / \mathrm{min} / 1.73 \mathrm{~m}^{2}$, the initial dose of insulin should be decreased by as much as 50 percent [18]. In summary, an impaired renal function may significantly affect the pharmacokinetics of the most antihyperglycemic agents, which may result in a higher risk of side effects, especially hypoglycemia [19]. Therefore,it is important to check renal function regularly and monitor the progression of kidney disease in the patients with diabetes. The choice and dosage of antihyperglycemic agents should be reviewed and re-adjusted as eGFR declines.

\section{References}

1. Tuttle KR, Bakris GL, Bilous RW, Chiang JL, De Boer IH, et al. (2014) Diabetic kidney disease: a report from an ADA Consensus Conference. Am J Kidney Dis 64(4): 510-533.

2. Wu B, Bell K, Stanford A, Kern DM, Tunceli O, et al. (2016) Understanding CKD among patients with T2DM: prevalence, temporal trends, and treatment patterns-NHANES 2007-2012. BMJ Open Diabetes Res Care $4(1)$.
3. Gerich JE, Meyer C, Woerle HJ, Stumvoll M (2001) Renal gluconeogenesis: its importance in human glucose homeostasis. Diabetes Care 24(2): 382391.

4. (2012) National kidney foundation KDOQI clinical practice guideline for diabetes and CKD. Am J Kidney Dis 60(5): 850-886.

5. (2016) FDA drug safety communication: FDA revises warnings regarding use of the diabetes medicine metformin in certain patients with reduced kidney function.

6. Balant L, Zahnd G, Gorgia A, Schwarz R, Fabre J (1973) Pharmacokinetics of glipizide in man: influence of renal insufficiency. Diabetologia, pp. 331-338.

7. Arnouts P, Bolignano D, Nistor I, Bilo H, Gnudi L, et al. (2014) Glucoselowering drugs in patients with chronic kidney disease: a narrative review on pharmacokinetic properties. Nephrol Dial Transplant 29(7): 1284-1300.

8. Davies M, Chatterjee S, Khunti K (2016) The treatment of type 2 diabetes in the presence of renal impairment: what we should know about newer therapies. Clin Pharmacol 8: 61-81.

9. Giorda CB, Nada E, Tartaglino B (2014) Pharmacokinetics, safety and efficacy of DPP-4 inhibitors and GLP-1 receptor agonists in patients with type 2 diabetes mellitus and renal or hepatic impairment. A systematic review of the literature. Endocrine 46(3): 406-419.

10. Huttner S, Graefe-Mody EU, Withopf B, Ring A, Dugi KA (2008) Safety, tolerability, pharmacokinetics and pharmacodynamics of single oral doses of BI 1356, an inhibitor of dipeptidyl peptidase 4, in healthy male volunteers. J Clin Pharmacol 48(10): 1171-1178.

11. Linnebjerg H, Kothare PA, Park S, Mace K, Reddy S, Mitchell M, et al. (2007) Effect of renal impairment on the pharmacokinetics of exenatide. Br J Clin Pharmacol 64(3): 317-327.

12. Scheen AJ (2015) Pharmacokinetics and clinical use of incretin-based therapies in patients with chronic kidney disease and type 2 diabetes. Clin Pharmacokinet 54(1): 1-21.

13. Sahasrabudhe V, Terra SG, Hickman A, Saur D, Shi H, O Gorman M, et al. (2017) The effect of renal impairment on the pharmacokinetics and pharmacodynamics of ertugliflozin in subjects with type 2 diabetes mellitus. J Clin Pharmacol 57(11): 1432-1443.

14. Invokana highlights of prescribing information. pp. 1-18.

15. Empagliflozin (2014) Highlights of prescribing information. pp: 1-27.

16. Jeffrey SB, Joel DG (2017) Management of hyperglycemia in patients with type 2 diabetes and pre-dialysis chronic kidney disease or endstage renal disease.

17. American Diabetes Association (2018) 8. Pharmacologic approaches to glycemic treatment: standards of medical care in diabetes. Diabetes Care 41(1): S73-S85.

18. Garber AJ, Abrahamson MJ, Barzilay JI, Blonde L, Bloomgarden ZT, et al. (2018) Consensus statement by the american association of clinical endocrinologists and american college of endocrinology on the comprehensive type 2 diabetes management algorithm. Endocr Pract 23(2): 207-238.

19. Neumiller JJ, Hirsch IB (2015) Management of hyperglycemia in diabetic kidney disease. Diabetes Spectr 28(3): 214-219. 
Creative Commons Attribution 4.0 International License

For possible submissions Click Here

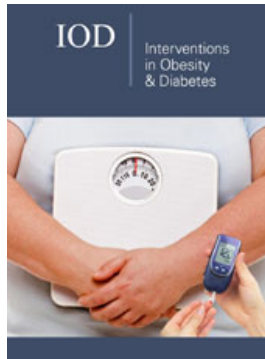

\section{Intervention in Obesity \& Diabetes}

\section{Benefits of Publishing with us}

- High-level peer review and editorial services

- Freely accessible online immediately upon publication

- Authors retain the copyright to their work

- Licensing it under a Creative Commons license

- Visibility through different online platforms 